\title{
Guidance for switching from off-label antipsychotics to pimavanserin for Parkinson's disease psychosis: an expert consensus
}

Kevin J. Black, Henry Nasrallah, Stuart Isaacson, Mark Stacy, Rajesh Pahwa, Charles H. Adler, Gustavo Alva, Jeffrey W. Cooney, Daniel Kremens, Matthew A. Menza, Johnathan M. Meyer, Ashwin A. Patkar, Tanya Simuni, Debbi A. Morrissette, and Stephen M. Stahl

In the original publication "Guidance for switching from off-label antipsychotics to pimavanserin for Parkinson's disease psychosis: an expert consensus," by Black et al.
(2018), the authors regret the errors found in Table 1; Boxes 1, 3, and 4; and Figure 1. The correct Table 1, Boxes 1, 3, and 4, and Figure 1 are given below.

TABLE 1. Receptor binding affinities for select antipsychotic agents

\begin{tabular}{|c|c|c|c|c|c|c|c|c|}
\hline Drug & $\underline{\mathrm{D}}_{\underline{2}}$ & $\underline{\mathbf{5 H T}}_{1 \mathrm{~A}}$ & $\underline{\mathbf{5 T}}_{\underline{2 A}}$ & $\alpha_{1 A}$ & $\underline{\alpha}_{\underline{2 c}}$ & $\begin{array}{c}\underline{\mathrm{M}}_{1} \\
\text { (central) }\end{array}$ & $\stackrel{\mathrm{M}_{2-4}}{\underline{\text { (peripheral) }}}$ & $\underline{\mathrm{H}}_{\underline{1}}$ \\
\hline Pimavanserin & - & - & ++++ & - & - & - & - & - \\
\hline Haloperidol & ++++ & - & ++ & ++ & ++ & - & - & - \\
\hline Clozapine & ++ & - & +++ & +++ & ++ & ++ & +++ & ++++ \\
\hline Olanzapine & +++ & - & +++ & + & - & ++ & + & +++ \\
\hline Quetiapine & ++ & - & + & - & - & + & + & +++ \\
\hline Risperidone & ++++ & - & ++++ & +++ & ++ & - & - & ++ \\
\hline Effects of Blockade & $\begin{array}{l}\text { Antipsychotic, } \\
\text { antimanic, } \\
\text { antiagression, } \\
\text { EFS//akathisia, tardive } \\
\text { dyskinesia, increased } \\
\text { prolactin }\end{array}$ & $\begin{array}{l}\text { Anxiolytic, } \\
\text { antidepressant, anti } \\
\text { EPS/akathisia }\end{array}$ & $\begin{array}{l}\text { Anti-EPS/akathisia, } \\
\text { antipsychotic }\end{array}$ & $\begin{array}{l}\text { Postural } \\
\text { hypotension, } \\
\text { dizziness, syncope }\end{array}$ & $\begin{array}{l}\text { Antidepressant, } \\
\text { nncreased alertness, } \\
\text { increased blood } \\
\text { pressure }\end{array}$ & $\begin{array}{l}\text { Memory, cognition, } \\
\text { dry mouth, anti- } \\
\text { EPS/akathisia }\end{array}$ & $\begin{array}{l}\text { Blurred vision, } \\
\text { constipation, } \\
\text { urinary retention, } \\
\text { tachycardia, } \\
\text { iypertension }\end{array}$ & $\begin{array}{l}\text { Anxiolytic, sedation, } \\
\text { sleep induction, } \\
\text { weight gain, anti- } \\
\text { EPS/akathisia }\end{array}$ \\
\hline $\begin{array}{c}\text { Potential } \\
\text { Withdrawal/ } \\
\text { Rebound Effects }\end{array}$ & $\begin{array}{l}\text { Psychosis, manaia, } \\
\text { gaitation, akathisia, } \\
\text { withdrawal dyskinesia }\end{array}$ & $\begin{array}{l}\text { Anxiety, } \\
\text { EPS/akathisia }\end{array}$ & $\begin{array}{l}\text { EPS/akathisia, } \\
\text { psychosis }\end{array}$ & $\begin{array}{l}\text { Tachycardia, } \\
\text { hypertension }\end{array}$ & Hypotension & $\begin{array}{l}\text { Agitation, confusion, } \\
\text { psychosis, anxiety, } \\
\text { insomnia, } \\
\text { sialorihoea, } \\
\text { EPS/akathisia }\end{array}$ & $\begin{array}{l}\text { Diarrhea, sweating, } \\
\text { hausea, vomiting, } \\
\text { bradycardia, } \\
\text { hypotension, } \\
\text { pyncope }\end{array}$ & $\begin{array}{l}\text { Anxiety, agitation, } \\
\text { insomnia, } \\
\text { restlessness, } \\
\text { EPS/akathisia }\end{array}$ \\
\hline
\end{tabular}

+ weak binding affinity $(100>\mathrm{Ki}<1000)$

++ moderate binding affinity $(10>\mathrm{Ki}<100)$

+++ strong binding affinity $(1>\mathrm{Ki}<10)$

++++ very strong binding affinity $(K i<1)$

Abbreviations: $5-H T=$ serotonin; $\alpha=$ adrenergic; $D=$ dopamine; $H=$ histamine; $M=$ muscarinic.

$\mathrm{Ki}(\mathrm{nM})$ values are derived from functional antagonist R-SATM assays (ACADIA, San Diego, CA, USA).

“-" denotes no response.

Adapted from Hacksell et. al. Neurochem Res 2014; 39:2008-2017 and from data on file. 
Box 1. Dosing tips for switching to pimavanserin from low-dose ( $\leq 100 \mathrm{mg}$ ) Quetiapine (see Figure 3 )

- Add full dose (34 mg) pimavanserin to current low dose (up to $100 \mathrm{mg}$ ) quetiapine for 4 weeks

- Allows pimavanserin to reach steady state and the duration of treatment necessary to reach its delayed onset of therapeutic action

- Then reduce quetiapine by $50 \%$ weekly until reaching $12.5 \mathrm{mg}$, then discontinue

- If efficacy for PDP diminishes during quetiapine taper, can return to previous dose level and try tapering again in 1 week

\section{Box 3. Dosing tips for switching to pimavanserin from low-dose ( $\leq 100 \mathrm{mg}$ ) Clozapine (see Figure 5 )}

- Add full dose (34 mg) pimavanserin to continuing clozapine dose for 6 weeks

- Then reduce clozapine by $6.25 \mathrm{mg}$ weekly until discontinued and in no event, not less than 4 weeks of tapering

- If efficacy for PDP diminishes during clozapine taper, can return to previous dose level and try tapering again in 1 week

- Recommend not removing patient from clozapine registry for a few months in case clozapine must be restarted

\section{Box 4. Dosing tips for switching to pimavanserin from high-dose (>100 mg) Clozapine (see Figure 6)}

- Add full dose (34 mg) pimavanserin to continuing clozapine dose for 6 weeks

- Then reduce clozapine by $25 \mathrm{mg}$ weekly until discontinued and in no event, not less than 4 weeks of tapering

- If efficacy for PDP diminishes during clozapine taper, can return to previous dose level and try tapering again in 1 week

- Recommend not removing patient from clozapine registry for a few months in case clozapine must be restarted

FIGURE 1. Patients not currently taking antipsychotic medication. Start full dose of Pimavanserin immediately.

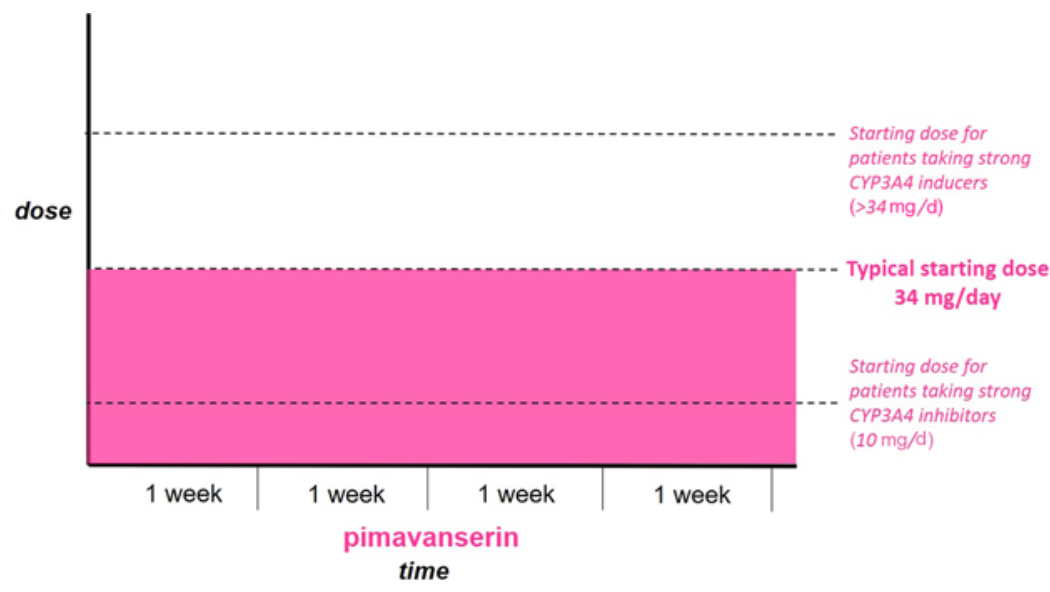

Page 407:

In addition, the authors would like to make the following text corrections and clarifications:

Page 405:

- $\quad$ The MDS EBM was published in 2011.

Page 406:

- The doses in the early phase $2 b / 3$ study were placebo, 8.5, and $34 \mathrm{mg} / \mathrm{d}$.

- The $P$-value for the hallucination and delusions subscales was 0.0012 .

- $\quad$ Sleep quality, caregiver burden, etc. were exploratory outcomes.
- The QT prolongation for pimavanserin is 5-8 msec.

The original publication has been corrected to reflect these changes.

\section{REFERENCE:}

Black K, Nasrallah H, Isaacson S, et al. (2018). Guidance for switching from off-label antipsychotics to pimavanserin for Parkinson's disease psychosis: An expert consensus. CNS Spectrums. 2018; 23(6):402-413 doi:10.1017/S1092852918001359 